
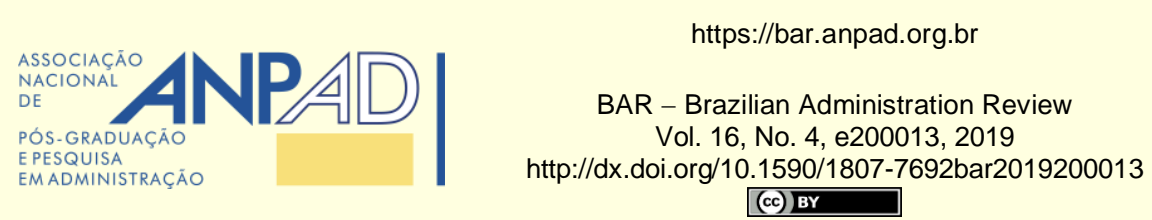

\title{
Editorial
}

\section{Business Models in Emerging Markets}

\author{
Germán Benito-Sarriá ${ }^{1}$ \\ Cristina Villar ${ }^{1}$ \\ ${ }^{1}$ University of Valencia, Valencia, Spain
}

Within the academic research, specific topics or terms appear and quickly gain great popularity, becoming a "must have" in journals and conferences. One of those terms that currently sounds loud is business model (BM). As the notion of BM started to emerge, the decade of 2000 encompassed certain skepticism necessary to improve the quality of scientific knowledge in this field, including that of renowned academics ${ }^{1}$. After this initial stage, the reasoning of BMs seems to be now widely acknowledged in management research.

Despite the current acceptance of BM by academics and practitioners, yet few people know what it really is (Klang, Wallnöfer, \& Hacklin, 2014). In early years, due to the confusion introduced by this term, prominent works made an attempt to differentiate it from the business strategy concept. Among the variety of available descriptions, two of them are widely used nowadays by BM researchers. Amit and Zott (2001) conceptualized BM as a system of interconnected activities, i.e., "the content, structure, and governance of transactions designed so as to create value through the exploitation of business opportunities" (p. 51). From a value-based perspective, Teece (2010) proposed that "a business model defines how the enterprise creates and delivers value to the customer, and then converts payments received to profits" (p. 173).

The contribution of BM lies in the creation of opportunities to study traditional business issues from a different lens (essentially, value offer and value creation). Nevertheless, BMs were mostly designed and explained within a traditional economy, and cannot be easily replicated globally (Landau, Karna, \& Sailer, 2016). Because customers are increasingly dispersed as well as activities are fragmented across global value chains, the peculiarity of the locations where the firm operates plays a very important role and define the value offered by the BM itself (Onetti, Zucchella, Jones, 
\& Mcdougall-Covin, 2012). Frequently, firms have approached emerging economies searching for a better endowment of resources, but these emerging markets open new avenues to attract new customers, often referred by literature as the base/bottom of the pyramid (BOP), and even test new business models. According to data from The World Bank (2019), in 2018 3,157 million people resided in the so-called BRICS, the five fastest growing emerging economies, mostly concentrated in India and China, with a population much higher than that of the developed regions (United Nations Statistical Division, n.d.).

Applying the business model logic in emerging markets therefore posits significant challenges for multinationals. Because of the different institutional context in emerging markets - often implying negative effects of institutional voids - the same efficiency characteristic should not be introduced as those of the traditional model. Instead, it is necessary to add elasticity in the business model to cover unexpected increases in demand (Sharma, Dixit, \& Karna, 2016) ${ }^{2}$. According to Amit and Zott (2012), innovation in the BM can be performed by redefining its content (adding new activities), its structure (linking activities differently), and its governance (changing parties that perform the activities). In this regard, global firms will need to cope with the increasing importance of reverse innovation, i.e., products developed to meet the needs of consumers in emerging markets. This places business model innovation as a key element for performance in these markets (Winterhalter, Zeschky, Neumann, \& Gassmann, 2017) . $^{3}$

In order to cope with the constraints and opportunities introduced by the institutional context of these new players, firms must innovate and establish collaborative relationships with local governments and institutions and others non-market actors such as non-profit organizations (NGOs) (Prahalad \& Hart, 2002). As postulated in the Agenda 2030, it takes important challenges at the economic, but also at the social level. According to The World Bank (2018), in 20183.4 billion people had great difficulty meeting their basic needs. Most of the poverty is concentrated in sub-Saharan Africa, but there is a large percentage of people with low incomes in many other regions, including emerging markets.

Pels and Sheth (2017) propose four types of viable BMs in emerging regions with high poverty rates. The basic type, Market Adaptation Business Model, is based on the adaptation of the original model to the restrictions of low-income consumers. Radically Different Business Models are based on the opportunities found in these regions. The remaining two models have a strong social focus: the Mission Focus Model and the Inclusive Ecosystem Model. A Mission Focus Model aims at correcting some of the weaknesses of the population through business (for instance, microfinance), while an Inclusive Ecosystem Model tries to take advantage of the interrelationships of market conditions to solve several problems simultaneously.

Inclusive business models seem particularly relevant in the long term for firms operating in emerging markets, as these entail the co-creation and co-governance of the model with nonmarket actors (Reficco \& Vernis, 2010). Multinationals must develop a global capability in social embeddedness, establishing these relationships with non-conventional partners, co-inventing custom solutions and building local capacities (London \& Hart, 2004). Firm/NGOs cooperation can help to complete each other's business model: collaboration with an NGO can provide the

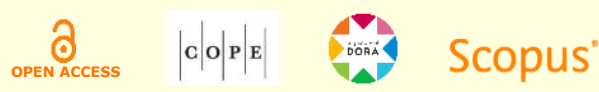


firms with market experience, legitimacy with customers, and access to resources, distribution systems, or local contacts (Dahan, Doh, Oetzel, \& Yaziji, 2010). On the other hand, the idea that multinationals can generate benefits and alleviate poverty simultaneously also has proponents and critics (Hillemann \& Verbeke, 2014) due to market failures that generate conflicts in these objectives (Karnani, 2011). The positive impact of spillovers derived from the presence of multinationals highly depends on the institutional context, where its effects vary depending on the degree of development of the host country. However, recent research is pointing at the benefits brought by multinationals in both advanced and emerging economies, stimulating local competition through different mechanisms (Villar, Mesa, \& Pla-Barber, in press). Further than the classic economic and productivity-based spillovers, the presence of foreign firms expands the range of possibilities for domestic firms to enhance their capabilities not only through the imitation of their products, but also by learning about the best organizational practices introduced by multinationals.

The nature of business models in global companies has a great impact on the societies where they operate. Whether social value is the main driver of the business or not, the social impact that firms have in these regions must be considered in the design of more sustainable business models (Joyce \& Paquin, 2016). Dimensions of social value creation related to the creation, distribution, and capture of economic value need to be integrated with BM for and from emerging markets. In this sense, we propose two main streams of research for future development. On the one hand, it would be interesting to analyze what are the factors fostering the consideration of social value creation as the main objective in the formulation of inclusive business models and its dynamics, such as the influence of context and institutions, as well as its link with the local development. On the other hand, a new typology of inclusive business models should be created to capture differences and similarities among alternative approaches to incorporate social value. Far from being a trend, the study of the BM is an important opportunity for researchers and practitioners to question our joint contribution to economic and social development.

By using a business model approach, we would like to invite the BAR community to deepen the foundations of social value creation in its research.

\section{Notes}

${ }^{1}$ For instance, Michael Porter (2001) stated that "the definition of a business model is murky at best. Most often, it seems to refer to a loose conception of how a company does business and generates revenue. Yet simply having a business model is an exceedingly low bar to set for building a company. Generating revenue is a far cry from creating economic value ..." (p. 73).

${ }^{2}$ A airline in India.

${ }^{3}$ Western and Indian medical devices and laboratory equipment multinationals in China and India. 


\section{References}

Amit, R., \& Zott, C. (2001). Value creation in e-business. Strategic Management Journal, 22(6-7), 493-520. https://doi.org/10.1002/smj.187

Amit, R., \& Zott, C. (2012). Creating value through business model innovation. MIT Sloan Management Review, 53(3), 41-49.

Dahan, N. M., Doh, J. P., Oetzel, J., \& Yaziji, M. (2010). Corporate-NGO collaboration: Co-creating new business models for developing markets. Long Range Planning, 43(2-3), 326-342. https://doi.org/10.1016/j.lrp.2009.11.003

Hillemann, J., \& Verbeke, A. (2014). An internalization theory perspective on the Bottom of the Pyramid. Progress in International Business Research, 8, 69-90. https://doi.org/10.1108/s1745-8862(2013)0000008009

Joyce, A., \& Paquin, R. L. (2016). The triple layered business model canvas: A tool to design more sustainable business models. Journal of Cleaner Production, 135, 1474-1486. https://doi.org/10.1016/j.jclepro.2016.06.067

Karnani, A. (2011). "Doing well by doing good": The grand illusion. California Management Review, 53(2), 69-86. https://doi.org/10.1525/cmr.2011.53.2.69

Klang, D., Wallnöfer, M., \& Hacklin, F. (2014). The business model paradox: A systematic review and exploration of antecedents. International Journal of Management Reviews, 16(4), 454-478. https://doi.org/10.1111/ijmr.12030

Landau, C., Karna, A., \& Sailer, M. (2016). Business model adaptation for emerging markets: A case study of a German automobile manufacturer in India. RED Management, 46(3), 480-503. https://doi.org/10.1111/radm.12201

London, T., \& Hart, S. L. (2004). Reinventing strategies for emerging markets: Beyond the transnational model. Journal of International Business Studies, 35(5), 350-370. https://doi.org/10.1057/palgrave.jibs.8400099

Onetti, A., Zucchella, A., Jones, M. V., \& McDougall-Covin, P. P. (2012). Internationalization, innovation and entrepreneurship: Business models for new technology-based firms. Journal of Management $\mathcal{B}$ Governance, 16(3), 337-368. https://doi.org/10.1007/s10997-010-9154-1

Pels, J., \& Sheth, J. N. (2017). Business models to serve low-income consumers in emerging markets. Marketing Theory, 17(3), 373-391. https://doi.org/10.1177/1470593117704262

Porter, M. E. (2001, March). Strategy and the internet. Harvard Business Review, 79(3), 63-78.

Prahalad, C. K., \& Hart, S. L. (2002). The fortune at the bottom of the pyramid. Strategy+ Business, 26, 54-67. Retrieved from https://www.strategy-business.com/article/11518?.pg=0

Reficco, E., \& Vernis, A. (2010). Engaging organizational ecosystems in inclusive business. In P. Márquez, E. Reficco, \& G. Berger (Eds.), Socially inclusive business: Engaging the poor through market initiatives in Iberoamerica (pp. 111 152). Cambridge: MA: Harvard University Press.

Sharma, S., Dixit, M. R., \& Karna, A. (2016). Design leaps: Business model adaptation in emerging economies. Journal of Asia Business Studies, 10(2), 105-124. https://doi.org/10.1108/jabs-01-2015-0009

The World Bank. (2018, October 17). Nearly half the world lives on less than $\$ 5.50$ a day. Retrieved from https://www.worldbank.org/en/news/press-release/2018/10/17/nearly-half-the-world-lives-on-less-than-550-a-day

The World Bank. (2019). Population, total. Retrieved February 20, 2020 from https://data.worldbank.org/indicator/SP.POP.TOTL

Teece, D. J. (2010). Business models, business strategy and innovation. Long Range Planning, 43(2-3), 172-194. https://doi.org/10.1016/j.lrp.2009.07.003

United Nations Statistical division. (n.d.). Methodology: Standard country or area codes for statistical use (M49). Retrieved February 20, 2020 from https://unstats.un.org/unsd/methodology/m49/ 
Villar, C., Mesa, R. J., \& Pla-Barber, J. (in press). A meta-analysis of export spillovers from FDI: Advanced versus emerging markets. International Journal of Emerging Markets.

Winterhalter, S., Zeschky, M. B., Neumann, L., \& Gassmann, O. (2017). Business models for frugal innovation in emerging markets: The case of the medical device and laboratory equipment industry. Technovation, 66, 3-13. https://doi.org/10.1016/j.technovation.2017.07.002

\section{Authors}

\section{Germán Benito-Sarriá}

University of Valencia, Faculty of Economics

Avda de los naranjos s/n 46022, Valencia, Spain

german.benito@uv.es

(iD) http://orcid.org/0000-0001-8238-0788

\section{Cristina Villar}

Associate editor, BAR - Brazilian Administration Review

University of Valencia, Faculty of Economics

Avda de los naranjos s/n 46022, Valencia, Spain

cristina.villar@uv.es

(iD) http://orcid.org/0000-0002-3304-8460 